\title{
Relationship Knowledge and The Level of Compliance with The Use of Masks During the Covid-19 Pandemic at Gatot Soebroto Hospital 2020
}

\section{Hubungan Pengetahuan dan Tingkat Kepatuhan terhadap Penggunaan Masker pada Masa Pandemi Covid-19 di RSPAD Gatot Soebroto Tahun 2020}

\author{
Leni Suhartini \\ STIKes RSPAD Gatot Soebroto \\ Jl. Abdul Rahman Saleh No. 24 Jakarta Pusat \\ lenibestari@gmail.com
}

Abstract

Casualties due to Covid-19 are increasing every day. The disease attacks the respiratory tract and transmitted through droplets when the sufferer speaks, coughs or sneezes. In some people do not cause symptoms, but in some patients there are also those that cause symptoms from mild to severe. Wearing a mask is one of the efforts made to prevent and protect from contaminated viruses. Objective: to assess the relationship of knowledge and the level of compliance with the use of masks during the Covid-19 pandemic. Research methods. Mused cross sectional method, sampled 32 respondents (consisting of 16 maternity room midwives and 16 final-level students). The data used is primary data collected using research instruments in the form of questionnaires distributed through google form. Analisys using Chi Square with tools of SPSS application. Result. In terms of knowledge obtained results in midwives good knowledge as many as 13 people (81,3\%) and less knowledge of 3 people (18,8\%). In good knowledge students as many as 10 people $(62,5 \%)$ and less knowledge of 6 people (37,5\%) $P$ value $=0,432$ and OR 0,385. From the level of compliance, midwives who do not comply with the use of masks as many as 5 people (31,3\%) and who obeyed as many as 11 people (68,8\%). Midwives students all are disobedient to the use of masks. Statistical test results obtained the value $p=0,001 \mathrm{OR}=0,313$. Conclusion. The use of masks is part of a comprehensive series of measures to prevent and control the spread of Covid-19 disease. High knowledge is not necessarily obedient to the use of masks, it is necessary awareness of each individual to use the mask according to the situation and conditions.

Keywords: masks, Covid-19, compliance, knowledge

\section{Abstrak}

Korban akibat Covid-19 meningkat setiap hari. Penyakit ini menyerang saluran pernafasan dan ditularkan melalui tetesan air ketika penderitanya berbicara, batuk atau bersin. Pada beberapa orang tidak menimbulkan gejala, namun pada beberapa penderita ada juga yang menimbulkan gejala dari yang ringan sampai yang berat. Memakai masker merupakan salah satu upaya yang dilakukan untuk mencegah dan melindungi dari virus yang tercemar. Tujuan: menilai hubungan pengetahuan dan tingkat kepatuhan penggunaan masker selama pandemi Covid-19. Metode penelitian. Metode Mused Cross Sectional, sampel 32 responden (terdiri dari 16 bidan ruang bersalin dan 16 siswa tingkat akhir). Data yang digunakan adalah data primer yang dikumpulkan dengan menggunakan instrumen penelitian berupa kuesioner yang disebarkan melalui Google Form. Analisis menggunakan Chi Square dengan alat bantu aplikasi SPSS. Hasil. Dari segi pengetahuan diperoleh hasil pengetahuan bidan baik sebanyak 13 orang $(81,3 \%)$ dan pengetahuan kurang 3 orang $(18,8 \%)$. Siswa berpengetahuan baik sebanyak 10 orang $(62,5 \%)$ dan pengetahuan kurang 6 orang $(37,5 \%)$ nilai $\mathrm{P}=0,432$ dan $\mathrm{OR} 0,385$. Dari tingkat kepatuhan bidan yang tidak patuh dalam penggunaan masker sebanyak 5 orang $(31,3 \%)$ dan yang patuh sebanyak 11 orang $(68,8 \%)$. Semua siswa bidan tidak patuh pada penggunaan masker. Hasil uji statistik diperoleh nilai $\mathrm{p}=0,001 \mathrm{OR}=0,313$. Kesimpulan. Penggunaan masker merupakan bagian dari rangkaian tindakan komprehensif untuk mencegah dan mengendalikan penyebaran penyakit Covid-19. Pengetahuan yang tinggi belum tentu patuh pada penggunaan masker, perlu adanya kesadaran dari setiap individu untuk menggunakan masker sesuai dengan situasi dan kondisi.

Kata kunci: masker, Covid-19, kepatuhan, pengetahuan. 


\section{PENDAHULUAN}

Memakai masker merupakan upaya yang dilakukan untuk mencegah dan mengendalikan penyakit pernafasan tertentu seperti Covid-19. Covid-19 menyebar kepada orang lain melalui droplet yang terpercik saat berbicara atau bersin. Droplet ini tidak bisa terbang jauh dan jatuh ke tanah dengan cepat. Oleh karena itu penting sekali untuk menjaga jarak dan memakai masker sebagai cara mencegah terpapar Covid-19. Droplet ini juga dapat menempel di benda mati seperti meja, gagang pintu dan handrail (WHO, 2020). Ada beberapa jenis masker yang dapat digunakan yaitu masker kain, masker bedah dan masker respirator medis seperti N95, FFP2 atau masker yang khusus digunakan oleh petugas layanan kesehatan saat merawat pasien Covid-19. Saat seseorang menggunakan masker maka droplet saat berbicara, batuk atau bersin tidak akan mengenai orang lain. Penggunaan masker dapat membantu melindungi orang-orang terdekat dari infeksi. Jika orang sakit perlu pergi ke fasilitas kesehatan, mereka harus menggunakan masker medis. Tetapi penggunaan masker yang salah juga tidak melindungi dari Covid-19.

Beberapa negara menyarankan penggunaan masker pada masyarakat umum sebelum 6 April 2020. Seperti USA, Canada, UK, Australia, New Zealand, Perancis, Italy, Spanyol, menganjurkan menggunakan masker di tempat kerja dan setelah kontak dengan tenaga kesehatan atau individu yang telah terpapar, di negara China menganjurkan masyarakat untuk menggunakan masker juga saat isolasi mandiri dan bila akan bepergian keluar rumah serta tempat lain yang memiliki ventilasi baik. (Tso \& Cowling, 2020). Studi kasus yang dilakukan di negara China mengenai penggunaan masker di masa pandemik hampir semua (99\%) orang mengenakan masker, sebagian besar $(73,3 \%)$ tingkat kepatuhan yang baik. Namun, 41,8\% responden jarang mencuci tangan sebelum memakai masker, dan lebih dari setengahnya $(55,3 \%, 62,1 \%)$ menyentuh $(\mathrm{n}=8108,79.8 \%)$ atau membetulkan posisi masker $(\mathrm{n}=9356$, $92.0 \%$ ). Saat melepas masker 7,6\% responden membuang masker bekas pakai ke tempat sampah tanpa tutup dan 22,5\% membuangnya ke tempat sampah terdekat tanpa menghiraukan ada tutupnya atau tidak. Responden mengenakan masker bedah sekali pakai $(93,8 \%)$, masker N95 (26,2\%), dan masker kain $(8,5 \%)$. Beberapa peserta mengenakan beberapa masker secara bersamaan (kadang-kadang 26,5\%, sering 2,1\%, selalu 1,5\%). Sebanyak $5.981(58,8 \%)$ responden menggunakan kembali masker sekali pakai, hampir dua pertiga $(n=3923,65,6 \%)$ responden menggantungkan masker di udara terbuka. Lebih dari sepertiga $(37,6 \%)$ responden tidak mengganti masker setelah digunakan lebih dari 8 jam (Tan et al., 2021).

Di Jepang, masyarakat sudah memiliki budaya menggunakan masker medis dalam kehidupan sehari-hari terutama selama musim flu. Hasil penelitian menemukan bahwa 83,5\% responden mengenakan masker dengan teliti, memastikan hidung dan mulut tertutup masker. Tingkat kepatuhan berkisar antara 38,3-62,9\%. 23,1\% responden patuh terhadap penggunaan masker yang benar (Machida et al., 2020). Masker sangat penting digunakan orang sakit (demam, batuk, bersin) atau mereka yang merawat orang sakit. Tenaga kesehatan, orang sakit, dan orang yang merawat orang sakit menggunakan masker medis. Orang sehat cukup menggunakan masker kain. (Kementerian Kesehatan Republik Indonesia, 2020)

Mahasiswa semester VI Prodi DIII Kebidanan STIKes RSPAD Gatot Soebroto dihentikan dari Praktik Klinik Kebidanan akibat pandemik Covid-19, mereka hanya praktik dua minggu yang seharusnya enam minggu. Saat lulus tidak menutup kemungkinan mereka akan turun ke lahan praktik dan mengatasi kasus maternal dan neonatal dengan di masa pandemik Covid-19. Bidan di kamar bersalin RSPAD Gatot Soebroto juga menangani kasus maternal dan neonatal yang terkonfirmasi Covid-19. Setiap hari pasien Covid-19 semakin bertambah. Berdasarkan data pada tanggal 26 Juli 2020 pasien yang dirawat di ruang tekanan negatif sebanyak sembilan pasien (BOR 100\%), lantai 2 sebanyak 18 pasien (BOR 80\%), lantai 3 sebanyak 17 pasien (BOR 85\%), lantai 4 sebanyak 16 pasien (BOR 88,8\%). Data di kamar bersalin dari bulan April sampai dengan Juli tahun 2020 terdapat 16 kasus persalinan dengan Covid-19 di RSPAD Gatot Soebroto. Dari latar belakang tersebut saya ingin membandingkan tingkat Pengetahuan dan Tingkat Kepatuhan Terhadap Penggunaan Masker Pada 
Masa Pandemi Covid-19 di RSPAD Gatot Soebroto tahun 2020 dengan melibatkan bidan dan mahasiswa sebagai responden.

\section{METODE}

Desain penelitian yang digunakan dalam penelitian ini adalah kuantitatif korelasi dengan metode survei yaitu penelitian yang dilakukan untuk meneliti hubungan pengetahuan dan tingkat kepatuhan terhadap penggunaan masker pada masa pandemi Covid 19 di RSPAD Gatot Soebroto tahun 2020. Data yang digunakan adalah primer dalam bentuk kuesioner yang disebarkan melalui Google Form. Sampel penelitian sebanyak 32 orang (16 bidan dan 16 mahasiswa). Analisis data dilakukan dengan bantuan SPSS. Data akan dianalisis secara univariat dan bivariat. Sebelum melakukan penelitian peneliti melayangkan surat persetujuan penelitian. Surat persetujuan penelitian disampaikan kepada UPPM STIKES RSPAD Gatot Soebroto dan dilanjutkan ke Komite Riset RSPAD Gatot Soebroto, setelah mendapatkan izin, peneliti mengambil data ke bidan di kamar bersalin RSPAD Gatot Soebroto.

\section{HASIL DAN PEMBAHASAN}

Hasil

Adapun hasil penelitian digambarkan pada tabel berikut.

Tabel 1. Hubungan Bidan/Mahasiswa Terhadap Pengetahuan Penggunaan Masker di Masa Pandemi Covid-19 di RSPAD Gatot Soebroto Tahun 2020

\begin{tabular}{|c|c|c|c|c|c|c|c|c|c|}
\hline \multirow[t]{3}{*}{ No } & \multirow[t]{3}{*}{ Kelompok } & \multicolumn{4}{|c|}{ Pengetahuan } & \multicolumn{2}{|c|}{ Total } & \multirow[t]{3}{*}{ OR } & \multirow[t]{3}{*}{$P$ value } \\
\hline & & \multicolumn{2}{|c|}{ Kurang } & \multicolumn{2}{|c|}{ Baik } & & & & \\
\hline & & & $\%$ & n & $\%$ & $\mathbf{n}$ & $\%$ & & \\
\hline 1 & Bidan & 3 & 18,8 & 13 & 81,3 & 16 & 100 & 0,385 & 0,432 \\
\hline \multirow[t]{2}{*}{2} & Alumni & 6 & 37,5 & 10 & 62,5 & 16 & 100 & & \\
\hline & Total & 9 & 28,1 & 23 & 71,9 & 32 & 100 & & \\
\hline
\end{tabular}

Sumber: Diolah (2020)

Berdasarkan tabel 1 dapat dilihat bahwa pada penelitian ini melibatkan mahasiswa semester VI di masa pandemik covid sebanyak 16 orang $(50 \%)$ dan bidan dari ruang tindakan dan persalinan RSPAD Gatot Soebroto sebanyak 16 orang $(50 \%)$ sehingga total responden sebanyak 32 orang. Dari segi pengetahuan didapatkan hasil pada bidan pengetahuan baik sebanyak 13 orang $(81,3 \%)$ dan pengetahuan kurang sebanyak 3 orang $(18,8 \%)$. Pada mahasiswa pengetahuan baik sebanyak 10 orang $(62,5 \%)$ dan pengetahuan kurang sebanyak 6 orang $(37,5 \%)$. Hasil uji statistik diperoleh nilai $p=0,432$ maka dapat disimpulkan tidak ada hubungan antara kelompok bidan dan mahasiswa terhadap pengetahuan penggunaan masker. Dari hasil analisis diperoleh nilai $\mathrm{OR}=0,385$ artinya bidan mempunyai peluang 0,385 kali mempunyai pengetahuan lebih baik mengenai penggunaan masker di masa pandemik Covid-19 dibandingkan mahasiswa.

Tabel 2. Hubungan Bidan/Mahasiswa Terhadap Kepatuhan Penggunaan Masker di Masa Pandemi Covid-19 di RSPAD Gatot Soebroto tahun 2020

\begin{tabular}{|c|c|c|c|c|c|c|c|c|c|}
\hline \multirow[t]{3}{*}{ No } & \multirow[t]{3}{*}{ Kelompok } & \multicolumn{4}{|c|}{ Tingkat Kepatuhan } & \multicolumn{2}{|c|}{ Total } & \multirow[t]{3}{*}{ OR } & \multirow[t]{3}{*}{ P value } \\
\hline & & \multicolumn{2}{|c|}{ Tdk patuh } & \multicolumn{2}{|c|}{ Patuh } & & & & \\
\hline & & & $\%$ & $\mathbf{n}$ & $\%$ & n & $\%$ & & \\
\hline 1 & Bidan & 5 & 31,3 & 11 & 68,8 & 16 & 100 & 0,313 & 0,001 \\
\hline \multirow[t]{2}{*}{2} & Alumni & 16 & 100 & 0 & 0 & 16 & 100 & & \\
\hline & Total & 21 & 65,6 & 11 & 34,4 & 32 & 100 & & \\
\hline
\end{tabular}

Sumber: Diolah (2020) 


\section{Relationship Knowledge and The Level of Compliance with The Use of Masks During the Covid-19}

Pandemic at Gatot Soebroto Hospital 2020

Leni Suhartini

STIKes RSPAD Gatot Soebroto

Pada tabel 2 dapat dilihat bahwa bidan yang tidak patuh terhadap penggunaan masker sebanyak 5 orang $(31,3 \%)$ dan yang patuh sebanyak 11 orang $(68,8 \%)$. Pada mahasiswa semuanya tidak patuh terhadap penggunaan masker. Hasil uji statistik diperoleh nilai $\mathrm{p}=0,001$ maka dapat disimpulkan ada hubungan antara kelompok bidan dan mahasiswa terhadap kepatuhan penggunaan masker. Dari hasil analisis diperoleh nilai $\mathrm{OR}=0,313$ artinya bidan mempunyai peluang 0,313 kali patuh terhadap penggunaan masker di masa pandemik covid 19 dibandingkan mahasiswa.

\section{Pembahasan}

Pengetahuan, sikap dan praktik yang baik, dari petugas kesehatan mengenai alat pelindung diri seperti pakaian, face shield, sarung tangan dan masker wajah saat merawat pasien terkonfirmasi Covid19 sangatlah penting (Ahmed et al., 2020). Hasil penelitian yang dilakukan di RSPAD Gatot Soebroto dari segi pengetahuan didapatkan kesimpulan bahwa bidan mempunyai pengetahuan baik sebanyak 13 orang $(81,3 \%)$ dan pengetahuan kurang sebanyak 3 orang $(18,8 \%)$. Pada mahasiswa pengetahuan baik sebanyak 10 orang $(62,5 \%)$ dan pengetahuan kurang sebanyak 6 orang $(37,5 \%)$. bidan yang tidak patuh terhadap penggunaan masker sebanyak 5 orang $(31,3 \%)$ dan yang patuh sebanyak 11 orang $(68,8 \%)$. Pada mahasiswa semuanya tidak patuh terhadap penggunaan masker. Pengalaman menggunakan masker dan menerapkan protokol kesehatan menjadi faktor lingkungan yang dapat mempengaruhi pengetahuan seseorang. Pada mahasiswa pengalaman praktik klinik hanya diperoleh selama masa dinas menjalankan praktik klinik kebidanan dari kampus, dan terhenti dinasnya saat Indonesia menetapkan Covid-19 sebagai pandemik. Berbeda sekali dengan bidan yang sudah bekerja di RSPAD Gatot Soebroto, mereka sudah terbiasa dan membudaya penggunaan masker sehingga tingkat kepatuhan terhadap penggunaan masker lebih baik.

Pengetahuan atau kognitif merupakan domain yang sangat penting untuk terbentuknya tindakan seseorang. Pengetahuan dipengaruhi oleh faktor internal, faktor eksternal dan faktor belajar. Faktor internal adalah faktor yang berasal dari dalam diri sendiri ini meliputi dua aspek yaitu aspek fisiologis dan aspek psikologis. Faktor eksternal juga terdiri dari dua macam yaitu faktor lingkungan sosial dan faktor lingkungan non sosial. Lingkungan sosial yang dimaksud adalah orang tua, keluarga, teman, dan masyarakat di lingkungan tempat tinggal. Faktor nonsosial adalah rumah tempat tinggal dan letaknya, alat-alat belajar, keadaan cuaca dan waktu belajar. Semua faktor tersebut dapat mempengaruhi tingkat keberhasilan belajar dan penyerapan pengetahuan.

Kementerian Kesehatan dari negara-negara yang menganjurkan pemakaian masker menyatakan bahwa masker wajah akan efektif digunakan apabila penggunaannya tepat dan diikuti kebersihan tangan yang benar. Masyarakat umum diwajibkan menggunakan masker, namun muncul permasalahan ketika persediaan masker kurang dan masyarakat tidak memakai masker dengan tepat. Hal ini dapat mengurangi kepatuhan dan perilaku penggunaan masker (Tso \& Cowling, 2020). Daya filtrasi masker baik pada masker bedah atau masker kain dapat mengurangi penyebaran infeksi virus di udara. Selama pandemi Covid-19, memakai masker menjadi kewajiban sebagai pencegahan masuknya virus ke dalam tubuh. Tetapi di pihak lain limbah masker juga meningkat yang menimbulkan masalah bagi lingkungan (Hartanto \& Mayasari, 2021). WHO bekerja sama dengan badan penelitian dan pengembangan mitra dan komunitas ilmiah untuk meneliti masker kain. WHO menyarankan penggunaan masker bedah dan masker kain sesuai dengan kebutuhan. Penelitian ini untuk menilai apakah covid19 dapat menembus masker kain pada saat orang tersebut batuk, bersin atau berbicara (WHO, 2020).

Abboah (2021) melakukan percobaan acak untuk menilai efektivitas masker wajah untuk melindungi dari penularan virus corona. Respirator yang dipakai oleh tenaga kesehatan dinilai efektif bila dipakai terus menerus, namun masker medis dan masker kain dinilai kurang efektif (Abboah-Offei et al., 2021). Risiko tertular SARS-CoV-2 dilaporkan 36,9 kali lebih tinggi pada mereka yang tidak menggunakan masker (Wang et al., 2020). WHO membuat panduan mengenai cara merawat pasien dengan terkonfirmasi Covid-19 atau suspect Covid-19 yang memerlukan isolasi mandiri di rumah. Perawatan di rumah dapat dilakukan ketika RS penuh dan tidak ditemukan penyakit penyerta pada diri pasien. Petugas Kesehatan dapat melakukan verifikasi apakah pasien dan keluarga dapat mengikuti peraturan yang dianjurkan untuk isolasi mandiri di rumah seperti mencuci tangan, menjaga kebersihan 
lingkungan, tidak keluar rumah, termasuk keselamatan seperti bahaya kebakaran pada pengguna handrub yang mengandung alkohol (WHO, 2020).

WHO juga menerbitkan panduan tentang penggunaan masker yang benar, yaitu mencuci tangan sebelum memakai masker, memakai masker dengan tepat menutupi hidung dan mulut, minimalkan celah antara wajah dan masker, hindari menyentuh masker saat dipakai, melepaskan masker dengan teknik yang benar, mencuci tangan Kembali setelah melepaskan masker, mengganti masker dengan yang baru bila masker lama terasa lembap, dan membuang masker setelah sekali pakai. Dinamika epidemiologi Covid-19 suatu negara, kepatuhan, efektivitas serta keberhasilan langkah-langkah pencegahan infeksi ditentukan oleh pengetahuan sikap dan perilaku masyarakat negara tersebut (Christopher et al., 2020). Pengetahuan, sikap, dan praktik penyedia layanan kesehatan mengenai penggunaan masker bedah ditemukan baik namun tetap diperlukan kesadaran lebih lanjut mengenai beberapa aspek seperti jenis masker, lama penggunaan masker dan pembuangan masker. Lokakarya, Konferensi, dan kuliah pendidikan berkelanjutan diperlukan untuk meningkatkan kesadaran penyedia layanan kesehatan mengenai penggunaan masker yang tepat (Ahmed et al., 2020)

\section{PENUTUP}

Penggunaan masker merupakan bagian dari rangkaian komprehensif langkah pencegahan dan pengendalian dari penyebaran penyakit Covid-19. Masker dapat digunakan baik untuk melindungi orang yang sehat (dipakai untuk melindungi diri sendiri saat kontak dengan orang yang terinfeksi) atau untuk mengendalikan sumber (dipakai oleh orang yang terinfeksi untuk mencegah penularan lebih lanjut). Pengetahuan yang tinggi belum tentu patuh terhadap penggunaan masker, diperlukan kesadaran dari setiap individu untuk menggunakan masker sesuai situasi dan kondisi. Ketepatan penggunaan masker kain, masker bedah dan masker N95 perlu ditingkatkan lagi.

\section{DAFTAR PUSTAKA}

Abboah-Offei, M., Salifu, Y., Adewale, B., Bayuo, J., Ofosu-Poku, R., \& Opare-Lokko, E. B. A. (2021). A rapid review of the use of face mask in preventing the spread of COVID-19. International Journal of Nursing Studies Advances, 3(October 2020), 100013. https://doi.org/10.1016/j.ijnsa.2020.100013

Ahmed, N. J., Alanazi, O. S., Alzahrani, A. A., \& Alonazi, R. E. (2020). Knowledge , Practices and Attitude of Healthcare Providers about Using Face Mask to Limit the Spread of the Novel Coronavirus Disease. 32(13), 41-46. https://doi.org/10.9734/JPRI/2020/v32i1330581

Christopher, R., Margaret, R., Dauda, M. A. D., Saleh, A., \& Ene, P. (2020). Knowledge , Attitudes and Practices Towards COVID - 19: An Epidemiological Survey in North - Central Nigeria. Journal of Community Health, 0123456789. https://doi.org/10.1007/s10900-020-00881-1

Hartanto, B. W., \& Mayasari, D. S. (2021). Environmentally friendly non-medical mask: An attempt to reduce the environmental impact from used masks during COVID 19 pandemik. Science of the Total Environment, 760, 144143. https://doi.org/10.1016/j.scitotenv.2020.144143

Kementerian Kesehatan Republik Indonesia. (2020). Flyer Cara Memakai Masker.

Machida, M., Nakamura, I., Saito, R., Nakaya, T., Hanibuchi, T., Takamiya, T., Odagiri, Y., Fukushima, N., Kikuchi, H., Amagasa, S., Kojima, T., Watanabe, H., \& Inoue, S. (2020). Incorrect use of face masks during the current COVID-19 pandemik among the general public in Japan. International Journal of Environmental Research and Public Health, 17(18), 1-11. https://doi.org/10.3390/ijerph17186484

Tan, M., Wang, Y., Luo, L., \& Hu, J. (2021). How the public used face masks in China during the coronavirus disease pandemik: A survey study. International Journal of Nursing Studies, 115, 103853. https://doi.org/10.1016/j.ijnurstu.2020.103853

Tso, R. V., \& Cowling, B. J. (2020). Importance of Face Masks for COVID-19: A Call for Effective Public Education. Clinical Infectious Diseases, 71(16), 2195-2198. https://doi.org/10.1093/cid/ciaa593

Wang, X., Pan, Z., \& Cheng, Z. (2020). Letter to the editor Association between 2019-nCoV transmission and N95 respirator use. Journal of Hospital Infection, 105(1), 104-105. https://doi.org/10.1016/j.jhin.2020.02.021

WHO. (2020). Advice on the use of masks in the context of COVID-19. In Who (Issue April, pp. 1-5). https://www.who.int/publications- 